\title{
Effect of hydrochlorothiazide with amiloride on serum lipid profile and malondialdehyde in hypertensive women
}

\author{
Faris A. Ahmed \\ Department of Physiology, Nineveh College of Medicine, University of Mosul.
}

(Ann. Coll. Med. Mosul 2010; 36 (1 \& 2): 36-40).

Received: $11^{\text {th }}$ May 2010; Accepted: $27^{\text {th }}$ Oct 2010.

\begin{abstract}
Objectives: To study the effect of hydrochlorothiazde with amiloride on serum lipid profile and malondialdehyde (MDA) in hypertensive women.

Methods: A case-control study was carried out in the Outpatient Department in Ibn-Sina General Hospital, Mosul, during the period from November 2005 to May 2006. Thirty hypertensive women treated with $50 \mathrm{mg}$ hydrochlorothiazide and $5 \mathrm{mg}$ amiloride per day in a single dose. The duration of treatment was between 1-5 years. Thirty mild hypertensive women (newly diagnosed, before treatment) were also included as a control group. Blood samples were taken from both the treated patients and controls and analysed for serum lipid profile and MDA. Non-paired 't-test was used to compare between parameters.

Results: Hydrochlorothiazide with amiloride did not change serum lipid profile significantly in the hypertensive women compared with the control group, although serum lipid profile was in the upper normal value. The combination therapy decreased serum MDA significantly $(P<0.05)$.

Conclusion: Chronic use of combination therapy of hydrochlorothiazide with amiloride had no significant effect on serum lipid profile, but this combination reduced lipid peroxidation in hypertensive women. Lipid peroxidation is a consequence and not a cause of hypertension.
\end{abstract}

Keywords: Lipid profile, lipid peroxidation, malondialdehyde, hypertensive women.

الخلاصة

أهداف البحث: دراسة تأثير عقار هايدروكلوروثايز ايد مع عقار اميلور ايد على مصل واجهة الدهون ومصل مالوندالدهايد

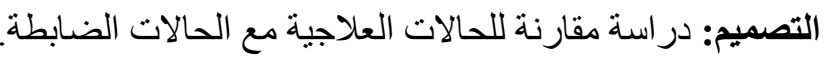

مكان إجراء الدراسة: تمت الدر اسة في العيادة الخارجية في مستشفى ابن سينا العام في الموصل للفترة من تشرين الثاني

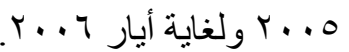

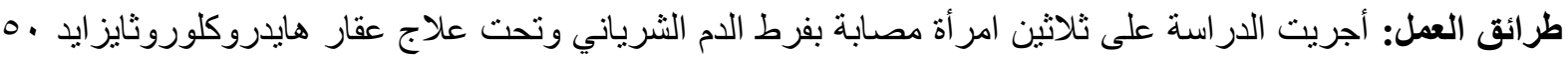

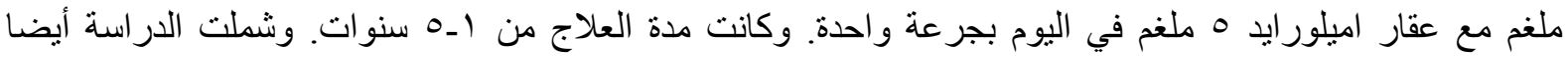

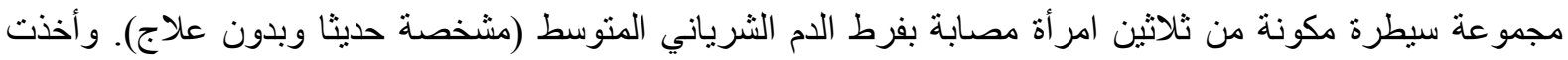
عينات الدم من كلا المجمو عتين للحصول على مصل و اجهة الدهون ومصل مالون الدين الدالدهايد. وتمت المقارنة بين المجمو عتين

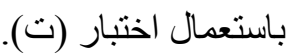
النتائج: لم يغير عقار هايدروكلوروثايزايد مع عقار اميلور ايد مصل واجهة الدهون في النساء المصابات بفرط الدم الدام

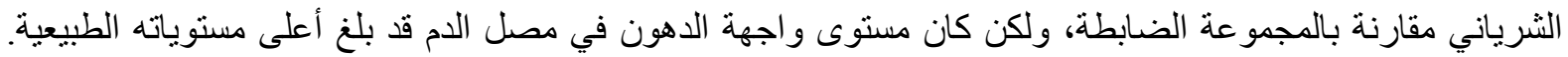

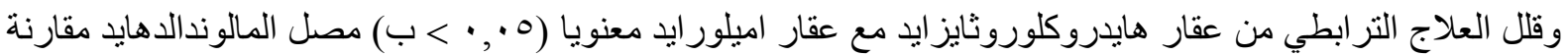
مع المجموعة الضابطة. 
الاستتتاج: إن الاستعمال المزمن للعلاج التو افقي لعقار هايدروكلوروثايز ايد مع عقار اميلور ايد لم يؤثر معنويا على واجهة

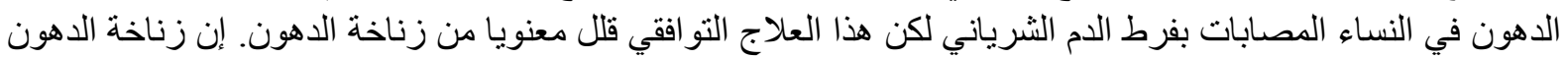
هي نتيجة وليست سبب ارتفاع ضغط الدم الثرياني.

$\mathrm{T}$ hiazides are moderately potent diuretics that increase urine flow, sodium and potassium excretion ${ }^{(1)}$. Hydrochlorothiazide has important effect on hypertension as a single therapy ${ }^{(2)}$. However, no trials have been done for evaluating the efficacy of amiloride, the potassium sparing diuretic, as a blood pressure lowering monotherapy ${ }^{(3)}$. The combination of hydrochlorothiazide and amiloride is used for the treatment of hypertension and the rational for combination is to spare potassium and magnesium loss through the kidney ${ }^{(4)}$.

Hydrochlorothiazide caused significant increase in serum triglycerides $(\mathrm{TG})^{(5)}$. Moser ${ }^{(6)}$ found that the rate of dyslipidaemia was higher with thiazide diuretics than loop diuretics. However, these disturbances in lipid profile were negligible at half standard dose of thiazide diuretics ${ }^{(7)}$. The potassium sparing diuretic, spironolactone, exerted no relevant effect on lipid profile ${ }^{(8)}$. There is well defined relationship between thiazide and dyslipidaemia but not with spironolactone ${ }^{(9)}$.

Lipid peroxidation of cell membrane was associated with a number of pathological conditions including atherosclerosis and thrombosis ${ }^{(10)}$. Essential hypertension was also associated with increased oxidative stress and reduced antioxidant status ${ }^{(11)}$. In addition, antihypertensive drugs and some diuretics exerted a positive effect on the imbalance between peroxide on lipid and antioxidant defense system ${ }^{(12)}$.

Usually, hydrochlorothiazide and amiloride are used in combination for the treatment of hypertension. Therefore, this study was conducted to evaluate the effect of this combination of drugs on serum lipid profile and lipid peroxidation presented by serum malondialdehyde (MDA).

\section{Patients and methods}

This study received approval from Nineveh Directorate of Health (Medical Research Ethical Committee, consents of patients were taken for this study). The study was carried out in the Outpatient Department in Ibn Sina Teaching Hospital in Mosul, from November 2005 to May 2006. Two groups of 30 female patients for each group were studied (under supervision of cardiologist). Patients of the first group received $50 \mathrm{mg}$ hydrochlorothiazide with $5 \mathrm{mg}$ amiloride per day in a single dose. The age of the treated patients ranged between 43-74 years (mean \pm SD: $51.8 \pm 7.6$ years). The duration of treatment was between 1-5 years. The second group included mild hypertensive patients (early diagnosed before treatment). Their ages ranged between 45-74 years (mean \pm SD: $51.6 \pm 7.6$ years). Patients with other diseases or receiving medication other than the studied drugs were excluded from this study.

Six $\mathrm{ml}$ of blood were collected from each patient, after overnight fasting. The sera were separated for the analysis of lipid profile and MDA. Determination of serum TC (total cholesterol), trigycerides (TG) and high density lipoprotein cholesterol (HDL-C) were performed by enzymatic methods ${ }^{(13-15)}$. Serum low density lipoprotein cholesterol (LDL-C) was calculated using Friedewald formula. ${ }^{(16)}$ Serum MDA was estimated by the method of Buege and Aust ${ }^{(17)}$.

Data are presented by mean $\pm S D$ and were analysed using unpaired t-test.

\section{Results}

In hypertensive patients treated with hydrochlorothiazide and amiloride, serum TC, TG, LDL-C, VLDL-C, HDL-C and ratio TC/HDL-C were not significantly different compared with the results in the non-treated patients (controls) (Table 1). However, values for serum lipid profile in the treated patients were in the upper normal limit based on the recommendation of British Hyperlipidaemia Association (1998) ${ }^{(18)}$.

Serum MDA was decreased significantly $(\mathrm{P}<0.05)$ in the treated patients compared with the non-treated patients (controls) (Table 1). 
Table (1): Serum lipid profile and malondialdehyde in the control group and treated patients with hydrochlorothiazide and amiloride.

\begin{tabular}{|c|c|c|c|c|c|c|c|}
\hline $\begin{array}{l}\text { Hypertensive } \\
\text { subjects }\end{array}$ & $\begin{array}{c}\mathrm{TC} \\
\mathrm{mmol} / \mathrm{L}\end{array}$ & $\begin{array}{c}\mathrm{TG} \\
\mathrm{mmol} / \mathrm{L}\end{array}$ & $\begin{array}{l}\text { LDL-C } \\
\mathrm{mmol} / \mathrm{L}\end{array}$ & $\begin{array}{l}\text { VLDL-C } \\
\mathrm{mmol} / \mathrm{L}\end{array}$ & $\begin{array}{l}\mathrm{HDL}-\mathrm{C} \\
\mathrm{mmol} / \mathrm{L}\end{array}$ & $\begin{array}{c}\mathrm{TC} \\
\mathrm{mmol} / \mathrm{L}\end{array}$ & $\begin{array}{r}\mathrm{MDA} \\
\mu \mathrm{mol} / \mathrm{L}\end{array}$ \\
\hline $\begin{array}{l}\text { Controls } \\
N=30\end{array}$ & $\begin{array}{c}4.08 \\
\pm 1.59 \\
\end{array}$ & $\begin{array}{c}1.30 \\
\pm 0.67 \\
\end{array}$ & $\begin{array}{c}2.18 \\
\pm 1.52 \\
\end{array}$ & $\begin{array}{c}0.59 \\
\pm 0.34 \\
\end{array}$ & $\begin{array}{c}1.3 \\
\pm 0.34 \\
\end{array}$ & $\begin{array}{c}3.53 \\
\pm 3.14 \\
\end{array}$ & $\begin{array}{c}0.204 \\
\pm 0.125 \\
\end{array}$ \\
\hline $\begin{array}{l}\text { Treated } \\
\text { patients } \\
\mathrm{N}=30\end{array}$ & $\begin{array}{r}4.99 \\
\pm 1.85\end{array}$ & $\begin{array}{c}1.66 \\
\pm 0.59\end{array}$ & $\begin{array}{l}3.09 \\
\pm 1.9\end{array}$ & $\begin{array}{c}0.75 \\
\pm 0.27\end{array}$ & $\begin{array}{c}1.15 \\
\pm 0.39\end{array}$ & $\begin{array}{c}4.87 \\
\pm 2.38\end{array}$ & $\begin{array}{l}0.134^{*} \\
\pm 0.069\end{array}$ \\
\hline
\end{tabular}

TC: total cholesterol; TG: triglycerides; LDL-c: low density lipoprotein cholesterol; VLDL-c: very low density lipoprotein cholesterol; MDA: malondialdehyde. ${ }^{*} \mathrm{P}<0.05$.

\section{Discussion}

In this study hydrochlorothiazide and amiloride combination did not produce significant change in serum lipid profile in the patients. However, many studies showed that thiazides cause dyslipidaemia ${ }^{(8,9)}$. Hydrochlorothiazide increased serum TG and VLDL- ${ }^{(19)}$. The effect of thiazides on lipids appears to be dose dependent, since higher dosage of hydrochlorothiazide increased serum TC and LDL-C ${ }^{(8)}$, whereas low dose of hydrochlorothiazide did not produce significant change in plasma lipid ${ }^{(20)}$.

The duration of treatment, in this study, was more than one year which may explain the minimal alteration in lipid profile caused by the treatment. These results are consistent with other workers ${ }^{(21,22)}$.

There are several theories of dyslipidaemia induced by diuretics, one theory suggested that thiazide induced reduction in insulin sensitivity might cause an associated increase in hepatic production of cholesterol ${ }^{(23)}$. This observation may be more related to the reduction in serum potassium occurred with high dose of thiazides ${ }^{(24)}$. The absence of even short term negative lipid effect of low doses of thiazides may be due to decreased incidence of hypokalaemia and associated insulin resistance ${ }^{(25)}$.

Accordingly, serum lipid profile did not change in the studied patients, since amiloride was used in the combination therapy to maintain potassium balance. In addition, amiloride did not increase blood levels of lipid $^{(26)}$. Also, there is well defined relationship between thiazides and dyslipidaemia but not with spironolactone $e^{(9)}$.

The combination of diuretics, in the present patients, decreased lipid peroxidation presented by serum MDA. Many studies showed an increase in lipid peroxidation accompanied with antioxidant imbalance in hypertensive patients ${ }^{(27,28)}$. Antihypertensive therapy decreased both blood pressure and oxidative stress in hypertensive patients ${ }^{(11,29)}$. Therefore, lipid peroxidation is a consequence and not a cause of hypertension ${ }^{(29)}$. However, the possibility that therapy targeted by decreasing generation of reactive oxygen species may be useful in minimizing vascular damage ${ }^{(30)}$.

In conclusion, chronic treatment of hydrochlorothiazide with amiloride did not change lipid profile in hypertensive women, but this combination decreased lipid peroxidation. Lipid peroxidation is a consequence and not a cause of hypertension.

\section{Acknowledgement}

This work was suppoted by Nineveh College of Medicine, University of Mosul, Iraq.

\section{References}

1. Ives HE. Diuretics agents in Basic and clinical pharmacology $10^{\text {th }}$ edition. Katzung BG (Ed). McGraw-Hill, New York, 2007; 236-253.

2. Chen JM, Heran BS, Wright JM. Blood pressure lowering efficacy of diuretics as second-line therapy for primary hypertension. Cochrane Database Syst Rev 2009; 7: CD007187. 
3. Heran BS, Chen JM, wang JJ, Wright JM. Blood pressure lowering efficacy of potassium-sparing diuretics (that block the epithelial sodium channel) for primary hypertension. Cochrane Database System Rev 2010; 20: CD008167

4. Fluster D. When do combinations of diuretics make sense? Ther Umsch 2009; 66: 725-9.

5. Nandeesha $\mathrm{H}$, Payithran $\mathrm{P}$, Madanmohan $T$. Effect of antihypertensive therapy on lipids in newly diagnoses essential hypertensive women. Angiology 2009; 60: 217-20.

6. Moser M. Why are physians not prescribing diuretics more frequently in the management of hypertension? JAMA 1998; 279: 1813-16.

7. Law MR, Wald NJ, Morris JK, Jordan RE. Value of low dose combination treatment with blood pressure lowering drugs: Analysis of 354 randomized trials. BMJ 2003; 326: 1427-30.

8. Weidmann $P$, de Courten $M$, Ferrari $P$, Bohlen L. Serum Lipoproteins during treatment with antihypertensive drugs. J Cardiovase Pharmacol 1993; 22 supp 6: S98-105.

9. Suter PM, Vetter W. Metabolic effects of antihypertensive drugs. J Hypertens suppl 1995; 13: S11-7.

10. Polidori MC, Pratico D, Parente B, Mariani E, Cecchetti R, Yao Y, et al. Elevated lipid peroxidation biomarkers and low antioxidant status in atherosclerotic patients with increased carotid or iliofemoral intima media thickness. J Investig Med 2007; 55: 163-7.

11. Tandon R, Sinha MK, Garg H, Khana R, Khanna HD. Oxidative stress in patients with essential hypertension. Nati Med J India 2005; 18: 297-9.

12. Serkova VK, Burdeinaia LV. Effect of antihypertensive therapy on indices for lipid peroxidation and antioxidant system in patients with hypertensive heart. Liak Sprava 2002; (5-6): 12-16.

13. Allian CC, Poon LS, Chan CS, Richmond W, Fu PC. Enzymatic determination of total serum cholesterol. Clin Chem 1974; 20: 470-5.

14. Fossati J, principe L. Serum triglycerides determined colorimetrically with an enzyme that produce hydrogen peroxide. Clin Chem 1982; 28: 2077-80.

15. Lopes-Virella MF, Stone P, Ellis S, Colwell JA. Cholesterol determination in high density lipoproteins separated by three different methods. Clin Chem 1977; 23 : 882-4.

16. Friedewald WT, Levy RI, Fredrickson DS. Estimation of the concentration of low density lipoprotein cholesterol in plasma without use of the preparative ultra centrifuge. Clin Chem 1972; 18: 499-502.

17. Buege JA, Aust SD. Microsomol lipid peroxidation. Methods Enzymol 1978; 52: 302-10.

18. Wood D. Joint British recommendations on prevention of coronary heart disease in clinical practice. Heart 1998;51: 1-29.

19. Nandeesha $H$, Pavithran $P$, Madanmohan $T$. Effect of antihypertensive therapy on serum lipids in newly diagnosed essential hypertensive men. Angiology 2009; 60: 217-20.

20. Ott SM, LaCroix AZ, Ichikawa LE, Scholes D, Barlow WE. Effect of Low-dose thiazide diuretics on plasma lipids: results from a double-blind, randomized clinical trail in older men and women. J Am Geriatr Soc 2003; 51: 340-7.

21. Rao RA, Hegde BM, Bhat EK, Vidyavathiu, Rao RR. Lipid profile studies in long term thiazide treated hypertensives. Postgrad Med J 1991; 67: 652-4.

22. Lakshmann MR, Reda DJ, Metersen BJ. Diuretic and $\beta$-blockers do not have adverse effects at layer on plasma lipid and lipoprotein profile in men with hypertension. Arch Intern Med 1999; 159: 551-8.

23. Ferrari $P$, Rasman $J$, Weidmann $P$. Antihypertensive agents, serum lipoproteins and glucose metabolism. Am J Cardiol 1991; 67: 26-35. 
24. Weir MR, Moser M. Diuretics and betablockersr is there a risk for dyslipidemia? Am Heart J 2000; 139: 174-184.

25. Neutel JM. Metabolic manifestations of low dose diuretics. Am J Med 1996; 100: 7182.

26. Chrysant SG, Luu TM. Effect of amiloride on arterial pressure and renal function. $\mathrm{J}$ Clin Pharmacol 1980; 20: 332-7.

27. Sahu S, Abraham R, Vedahalli R, Daniel M. Study of lipid profile, lipid peroxidation and vitamin $E$ in pregnancy induced hypertension. Indian J Physiol Pharmcol 2009; 53: 365-9.

28. Kedziora-kornatowska K, Czuczeiko J, Pawluk H, Kornatowski T, Motyl J, Szadujkis-Szadurski L, et al. The marker of oxidative stress and activity of antioxidant system in the blood of elderly patients with essential arterial hypertension. Cell Med Biol Lett 2004; 9: 635-41.
29. Khanna HD, Sinha MK, Khanna S, Tandon R. Oxidative stress in hypertension: associated with antihypertensive treatment. Indian J Physiol Pharmacol 2008; 52: 283- 7.

30. Touyz RM, Schiffrin EL. Oxidative stress in arterial hypertension: oxidative stress and hypertension. In: Atherosclerosis and oxidant stress- A new prospective Ed. Jordan L Holtzman, Springer USA 2008;51-78. 